\title{
THE CURRENT STAGE OF BIOTECHNOLOGICAL APPROACHES AND SYSTEMATIC REMARKS ON SOME SPONTANEOUS MEDICINAL PLANTS IN ROMANIA - REVIEW OF LITERATURE
}

\author{
RODICA CATANĂ ${ }^{*}$, ROXANA NICOARĂ, MARILENA ONETE \\ Institute of Biology Bucharest, Romanian Academy, 296 Splaiul Independentei, 060031, Bucharest, Romania
}

*corresponding author: catanarodica@yahoo.com

Manuscript received: July 2019

\begin{abstract}
This review presents the current state of biotechnological approaches for some spontaneous medicinal plants in Romania based on literature published throughout the worlds during the last decade. From a total of 122 species that were listed in 2014 as strictly forbidden for collection, 47 species were selected for a biotechnological investigation (based on both in vitro and biochemical studies). For 13 species without such studies, some systematic remarks are presented. In addition to the medicinal aspects, some of these species have other scientific importance (endemics, relicts, etc.) or present other problems such as uncertain taxonomy, very restricted distribution area, low seed germination, etc. In Romania, in the last 5 years, the interest in the biotechnological characteristics of these species has increased. Because medicinal plants represent a valuable source of products, studies on genetic variability, micropropagation, induction and characterisation of desirable metabolites will be helpful to achieve a better management for their sustainable use and conservation.
\end{abstract}

\section{Rezumat}

În acest articol este prezentat stadiul abordărilor biotehnologice pentru unele plante medicinale spontane din România, pe baza literaturii din ultimul deceniu. Dintr-un total de 122 de specii enumerate în 2014 ca fiind strict interzise pentru colectare, pentru 47 din specii au fost publicate, în întreaga lume, diverse studii biotehnologice (studii in vitro și studii biochimice). Pentru 13 dintre aceste specii, nu au fost identificate astfel de studii; în cazul lor fiind prezentate câteva remarci sistematice. Pe lângă aspectele medicinale, unele dintre specii au și importanță științifică (endemice, relicte etc.) sau prezintă anumite probleme cum ar fi taxonomia incertă, zona de distribuție foarte limitată, germinația mică a semințelor etc. În țara noastră, în ultimii 5 ani, interesul biotehnologic pentru aceste specii a crescut. Deoarece speciile de plante medicinale reprezintă o valoroasă sursă de produse, studii privind variabilitatea genetică, micropropagarea, inducerea și caracterizarea metaboliților secundari vor fi de ajutor pentru o gestionare mai bună a utilizării și conservării durabile a acestor plante.

Keywords: spontaneous medicinal plant, biotechnology, in vitro techniques, secondary metabolites

\section{Introduction}

All over the world, medicinal plants, together with aromatic and culinary herbs, include numerous species that can be applied in numerous industries like food, pharmaceutical, chemical and cosmetic based on their constituents. To underline the importance of plant species, experts from the Royal Botanical Gardens Kew have shown that, from the total number of plant species with documented uses, the highest proportion $(57.21 \%)$ are used as medicines [27].

Medicinal plant species (being natural resources provided by ecosystems) are part of ecosystem services [25] for human well-being. Human well-being is indirectly affected by biodiversity loss due to the disruption of ecosystem function. Loss of biodiversity reduces the resilience of ecosystems, making them more vulnerable to shocks and disturbances and thus less able to supply humans with the services we require [2]. Collection from the wild, loss of the habitat (through residential and commercial development), urbanisation, industrialisation and tourism developments as well as impacts from agriculture represent the most significant threats to these economically important species, affecting nearly half $(48 \%)$ of plants assessed as Threatened or Near Threatened in the Red List of Medicinal Plants in Europe [1].

Spontaneous medicinal plants collected from the wild, avoiding the pollution from agriculture management [10], represent an undisputable genetic resource, with a vast array of secondary metabolites available; less than $10 \%$ of the world's biodiversity has so far been evaluated for potential biological activity [9].

Due to the increasing demand for medicinal plants, there is a pressing need for conservation of these valuable resources. For a sustainable utilisation of wild medicinal plants included in Red Lists, it is important that legal stipulations are followed. The aim of conservation strategies is a sustainable development of valuable germplasm through in situ (in natural habitats) and ex situ (botanical gardens, seed banks, in vitro conservation) techniques. Recently, the larger- 
scale cultivation is representing part of conservation strategies [7]. Among the activities of a sustainable conservation programme are: proper identification, collection, characterisation, evaluation, propagation, disease elimination, storage and distribution [28]. For a sustainable use of medicinal plants (both wild/ spontaneous and cultivated), it is necessary to allow modern research technologies for the extraction of pharmacological substances, controlled breeding and conservation.

\section{Materials and Methods}

The bibliographic screening was performed in different scientific data bases like Web of Science, PubMed, ResearchGate, Google Scholar etc. Some non-indexed citations were analysed to supplement the searches. The literature spanned the period from 2007 to 2017. For this purpose, we used the following keywords: spontaneous, medicinal plant, biotechnology, ex situ conservation, in vitro techniques, secondary metabolites, systematic remarks, Red List, Romania. The language was limited to English and Romanian.

\section{Results and Discussion}

In the last decade (2007 - 2017), the use of biotechnological approaches in medicinal plants was emphasised by numerous published articles and reviews. Data from the Web of Science showed an ascending trend of publications concerning medicinal plants (endemic or not) to 2016 (Figure 1). However, only one article (published in 2012) described studies about species of medicinal plants whose collection is strictly forbidden.

Biotechnological approaches in plant science are represented by the use of in vitro techniques (tissue cultures, micropropagation) and molecular tools (characterisation of genetic diversity, genetic maps, marker assisted selection, genomics and genetic modification) [36]. These studies are helpful in formulating plans for management to preserve their genetic diversity and ensure their long-term survival. For rapid propagation of rare, endemic and/or endangered medicinal plants, micro-propagation has the greatest commercial and economical importance [33]. Propagation of medicinal plants using tissue culture depends on the part of the plant that is collected, the level of threat in the wild and market demand [29].

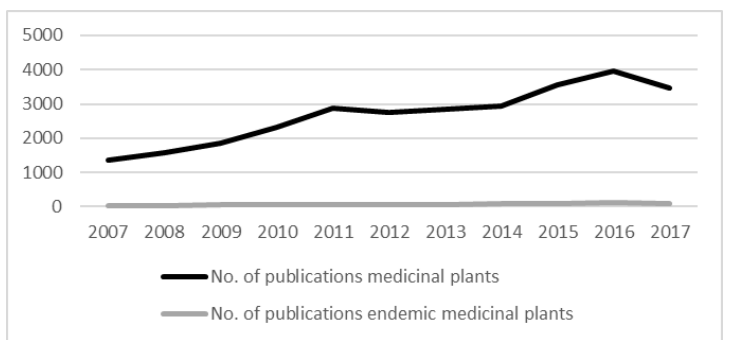

Figure 1.

Number of publications concerning biotechnological approaches of medicinal plant species in the last decade

In Romania, interest in herbal/traditional medicines and dietary supplements has increased for many consumers. In 2016, the value of sales of herbal/traditional products increased by $8 \%$, which represented better performance than the overall consumer health market (growing by 5\%) [39].

In Romania, 3,500 species of higher plants (spontaneous or cultivated) have been reported [8]. From the medicinal flora (represented by 900 species) almost 200 have been studied from a pharmaceutical point of view. Around 150 species are systematically harvested for medicinal or aromatic purposes and 50 species are cultivated [34].

In 2014, a list of the main spontaneous medicinal plants from Romania was published, totalling 756 species, of which 126 were threatened with extinction and 122 are strictly forbidden for collection [12].

Examining the most up-to-date literature on biotechnological approaches, of these 122 species, only 25 have recent studies, and 13 species had no in vitro or biochemical studies (Table I). For the 58 species where, only biochemical studies are available, in vitro techniques (micropropagation) are vital for a future sustainable use of natural resources, without endangering the species in the natural habitats.

While at international level the majority of the studies were regarding the investigation of active constituents and pharmacological activity, in Romania the newest studies were based more on ex situ conservation.

Table I

The state of spontaneous medicinal plants with recently biotechnological studies

\begin{tabular}{|c|c|}
\hline & No. of species \\
\hline Total no. of species strictly forbidden for collection & 122 \\
\hline No. of species without in vitro studies & 58 \\
\hline No. of species without biochemical studies & 25 \\
\hline No. of species without in vitro and biochemical studies & 13 \\
\hline
\end{tabular}

From the overall list of species that are strictly forbidden for collection and have no recent biotechnological approaches, 13 examples were selected (Table II), giving the vernacular name (in RO [12]; in ENG
[32]) and traditional usage. Where the vernacular name is given in brackets (e.g. [a reedmace or cattail]) the name applies to the genus as a whole, and the species has no unique vernacular name itself. 
Selected spontaneous medicinal plant species strictly forbidden for collection and traditional usage

\begin{tabular}{|c|c|c|}
\hline Plant species & $\begin{array}{l}\text { Vernacular name } \\
\text { RO/ENG }\end{array}$ & Traditional usage \\
\hline Adonis volgensis & /[a pheasant's-eye] & Cardiotonic, diuretic, sedative, vasoconstrictor [5] \\
\hline Aristolochia lutea & Mărul lupului/[a birthwort] & Anti-malaria [18] \\
\hline Calla palustris & Coada smeului/Bog arum & Against nettle-rash, skin irritations, wasp stings [30] \\
\hline Cimicifuga europaea & & Menopause symptoms [23] \\
\hline Cochlearia borzaeana & & Stimulates the kidneys, liver activity [30] \\
\hline Colchicum arenarium & Brândușă/Sand saffron & horticultural trade [4] \\
\hline $\begin{array}{c}\text { Dracocephalum } \\
\text { austriacum }\end{array}$ & Mătăciune/Pontic dragonhead & Cytotoxic activity, trypanocidal activity [22] \\
\hline Erysimum witmannii & $\begin{array}{c}\text { Micsandre sălbaticel } \\
\text { [a wallflower] }\end{array}$ & Cough, during acute benign bronchial disease [19] \\
\hline Jasminum fruticans & Iasomie/Wild jasmine & Antioxidant properties [16] \\
\hline $\begin{array}{l}\text { Lycopodium } \\
\text { tristachyum }\end{array}$ & $\begin{array}{l}\text { Brădişor/Blue clubmoss (or Blue } \\
\text { ground-cedar] }\end{array}$ & Anti-tumour, acetylcholinesterase inhibitory activity [37] \\
\hline Pyrola carpatica & Brăbănoi/Carpathian wintergreen & $\begin{array}{l}\text { Treatment of rheumatism, waist pain, knee pain and high blood } \\
\text { pressure [24] }\end{array}$ \\
\hline Ribes spicatum & Coacăz/Downy currant & Antioxidant activity and anti-inflammatory capacity [14] \\
\hline Typha shuttleworthii & Papură/[a reedmace or cattail] & Treatment of intestinal disorders and burns [11] \\
\hline
\end{tabular}

For most of this selection (11 species), Table III presents information on related species (together with guidance on taxonomic differentiation [31]) and active ingredients in both the species studied and in their relatives. Some of these rare species have very similar morphological characters to more common species, and distinguishing endangered species from their close relatives may be difficult for inexperienced or untrained people e.g. Typha species and Ribes species.

Distinguishing characters between medicinal plant species and their relatives, together with active ingredients

\begin{tabular}{|c|c|c|}
\hline \multicolumn{2}{|c|}{ Distinguishing characters } & \multirow{2}{*}{$\begin{array}{l}\text { Active ingredients of species or } \\
\text { their relatives }\end{array}$} \\
\hline Plant species & Related species & \\
\hline $\begin{array}{c}\text { Adonis volgensis } \\
\text { Leaves } 2 \text { - } 3 \text { times pinnately cut with ultimate } \\
\text { segments linear-lanceolate; } 1.5-3 \mathrm{~mm} \text { wide }\end{array}$ & $\begin{array}{c}\text { A. vernalis } \\
\text { Leaves } 2 \text { - } 4 \text { times pinnately cut with } \\
\text { ultimate segments linear; } 1 \mathrm{~mm} \text { wide }\end{array}$ & $\begin{array}{c}\text { convallatoxin, glycosides-cymarine, } \\
\text { adonitoxine, saponin phytosterine, } \\
\text { adonite, cardiac glycosides [6] }\end{array}$ \\
\hline $\begin{array}{c}\text { Aristolochia lutea } \\
\text { globular tuber; flowers solitary }\end{array}$ & $\begin{array}{c}\text { A. clematitis } \\
\begin{array}{c}\text { rhizome; flowers in groups of } 2-6(-8) \\
\text { in the axils of the leaves }\end{array}\end{array}$ & sterols, alkaloids, tannins [18] \\
\hline $\begin{array}{c}\text { Calla palustris } \\
\text { Plant aquatic or in boggy places, whose } \\
\text { broadly cordate leaves have parallel venation }\end{array}$ & $\begin{array}{c}\text { Arum maculatum } \\
\text { Plant always terrestrial, whose } \\
\text { triangular-hastate leaves have } \\
\text { reticulate venation }\end{array}$ & $\begin{array}{c}\text { saponins, cyanogenic compounds, } \\
\text { amines, flavonoids, flavanols } \\
\text { (quercetin and kaempferol), flavones, } \\
\text { luteolin, apigenin [15] }\end{array}$ \\
\hline $\begin{array}{l}\text { Colchicum arenarium } \\
\text { Style almost straight with a capitate stigma; } \\
\text { fruiting capsule } 10-20 \mathrm{~mm} \text { long and } 6-7 \mathrm{~mm} \\
\text { in diameter; leaves (if present) }<2 \mathrm{~cm} \text { wide. }\end{array}$ & $\begin{array}{c}\text { C. autumnale } \\
\text { Style curved and with stigma clearly } \\
\text { decurrent; leaves (if present) } 3-5 \mathrm{~cm} \\
\text { wide - rarely as narrow as } 2 \mathrm{~cm} \\
\end{array}$ & colchicine [26] \\
\hline $\begin{array}{c}\text { Dracocephalum austriacum } \\
\text { Leaves pinnately cut with } 3 \text { - } 7 \text { linear lobes }\end{array}$ & $\begin{array}{c}\text { Salvia pratensis } \\
\text { Leaves ovate-lanceolate, undivided } \\
\text { and with a sub-cordate base }\end{array}$ & $\begin{array}{l}\text { rosmarinic and caffeic acids, } \\
\text { flavonoids, diterpenes [22] }\end{array}$ \\
\hline $\begin{array}{c}\text { Erysimum witmannii } \\
\text { Perennial; petals large, } 18 \text { - } 25 \mathrm{~mm} \text { long, } \\
5-9 \mathrm{~mm} \text { wide; leaves sinuate - dentate }\end{array}$ & $\begin{array}{c}\text { E. cheiranthoides } \\
\text { Annual; petals } 3 \text { - } 6 \text { mm long; leaves } \\
\text { entire }\end{array}$ & $\begin{array}{l}\text { glucosinolates, mucilages, sugar } \\
\text { alcohols, flavonoids, cardiac steroid } \\
\text { glucosides, volatile compounds [19] }\end{array}$ \\
\hline $\begin{array}{c}\text { Jasminum fruticans } \\
\text { Yellow flowers; leaves either alternate or } \\
\text { opposite, pinnate, with } 3 \text { or } 5 \text { - } 7 \text { (rarely 9) } \\
\text { leaflets }\end{array}$ & $\begin{array}{c}\text { J. officinale } \\
\text { White flowers; pinnate leaves with at } \\
\text { least } 5 \text { leaflets }\end{array}$ & $\begin{array}{l}\text { alkaloids, carbohydrate, flavonoids, } \\
\text { saponins, tannins, terpenoids [16] }\end{array}$ \\
\hline $\begin{array}{c}\text { Lycopodium tristachyum } \\
\text { Stems \& branches weakly compressed, } \\
1.2-1.5 \mathrm{~mm} \text { wide; opaque, squamous leaves }\end{array}$ & $\begin{array}{c}\text { L. complanatum } \\
\text { Stems \& branches strongly } \\
\text { compressed; } 2-3 \mathrm{~mm} \text { wide }\end{array}$ & alkaloids [37] \\
\hline $\begin{array}{c}\text { Pyrola carpatica } \\
\text { Leaf elliptical with cuneate base \& petiole } \\
\text { longer than the limb }\end{array}$ & $\begin{array}{c}P . \text { rotundifolia } \\
\text { Leaf round with rounded base and } \\
\text { petiole shorter or equalling the limb }\end{array}$ & tannins, hyperoside, quercentin [38] \\
\hline
\end{tabular}


FARMACIA, 2020, Vol. 68, 2

\begin{tabular}{|c|c|c|}
\hline \multicolumn{2}{|c|}{ Distinguishing characters } & \multirow{2}{*}{$\begin{array}{l}\text { Active ingredients of species or } \\
\text { their relatives }\end{array}$} \\
\hline Plant species & Related species & \\
\hline $\begin{array}{c}\text { Ribes spicatum } \\
\text { lack of spines and glandular hairs, possession } \\
\text { of red fruit and bisexual flowers }\end{array}$ & $\begin{array}{c}\text { R. rubrum } \\
\text { saucer-shaped hypanthium and anther } \\
\text { lobes distinctly separated by connective }\end{array}$ & $\begin{array}{c}\text { flavanols, phenolic acids, } \\
\text { monoterpenes, vitamin C, catechins } \\
{[14]}\end{array}$ \\
\hline $\begin{array}{l}\text { Typha shuttleworthii } \\
\text { Female part of inflorescence is markedly } \\
\text { longer than the male; bristles at base of ovary } \\
\text { as long as stigma; seed } 0.7-0.9 \mathrm{~mm} \text { long; } \\
\text { leaves }<10 \mathrm{~mm} \text { wide. }\end{array}$ & $\begin{array}{c}\text { T. latifolia } \\
\text { Male and female parts of inflorescence } \\
\text { of similar length when fresh; stigma } \\
\text { longer than bristles at base of ovary; } \\
\text { seed } 1.4-1.7 \text { mm long; leaves }>10 \mathrm{~mm} \\
\text { wide }\end{array}$ & \begin{tabular}{|c|} 
quercetin- 3- neohesperidosid, \\
quercetin- and kaempferol-3- \\
glucoside, quercetin- and kaempferol- \\
3-galactoside [17]
\end{tabular} \\
\hline
\end{tabular}

Focussing on the presence of these species in the Romanian market, two of them are already used as part of the composition of some supplements. Uncontrolled exploitation will have a great impact on the species if the essential parts for survival (underground parts, flowers, seeds) are harvested. Removal or damaging of roots will affect the plant regeneration by reducing the water uptake, increasing the susceptibility to fungal infections. In the case of the spontaneous medicinal species listed by Dihoru \& Boruz [12], the most frequently used parts were whole plants $(42.85 \%)$, followed by underground organs $(33.33 \%)$, leaves $(23.80 \%)$, inflorescences (14.28\%) and seeds (4.76\%). In this context, the application of in vitro techniques may assure the multiplication of plant material used for secondary metabolites extraction and conservation of important plant genotypes.

Some of these medicinal plants also have scientific importance due to their toxic properties (Adonis volgensis), problems with taxon determination (Cochlearia borzaeana) or rarity (Dracocephalum austriacum). Adonis volgensis is confined to a restricted area with steppic conditions (in Romania), whilst Ribes spicatum and Cochlearia borzaeana are glacial relicts. $C$. borzaeana, Pyrola carpatica, Erysimum witmannii and Colchicum arenarium are endemic to Romania or to the Carpathians [13], being of biodiversity conservation importance internationally; their extinction could represent the loss of novel ecological interactions [20].

Some medicinal species present problems with seed viability. In the cases of Cimicifuga europaea and Calla palustris, seeds start to lose their viability soon after storage [40]. Adonis volgensis also has propagation problems, showing low seed production, failure of vegetative propagation and occasional attack by microscopic fungi [3].

A further insight into the species selected for the present paper is provided by Figure 2, which summarises their ecological distribution in Romania. Information on taxonomy, synonymy, local and international nomenclature can be useful in ensuring sustainable use of medicinal plants.

At the national level, spontaneous medicinal plants whose collection is strictly forbidden according to Ciocarlan, 2009 [8] are rare or sporadic (as measures of abundance) over more than one vegetation zone only a few (e.g. Adonis volgensis and Jasminum fruticans) are narrowly distributed and confined to one vegetation zone or level (Figure 2).

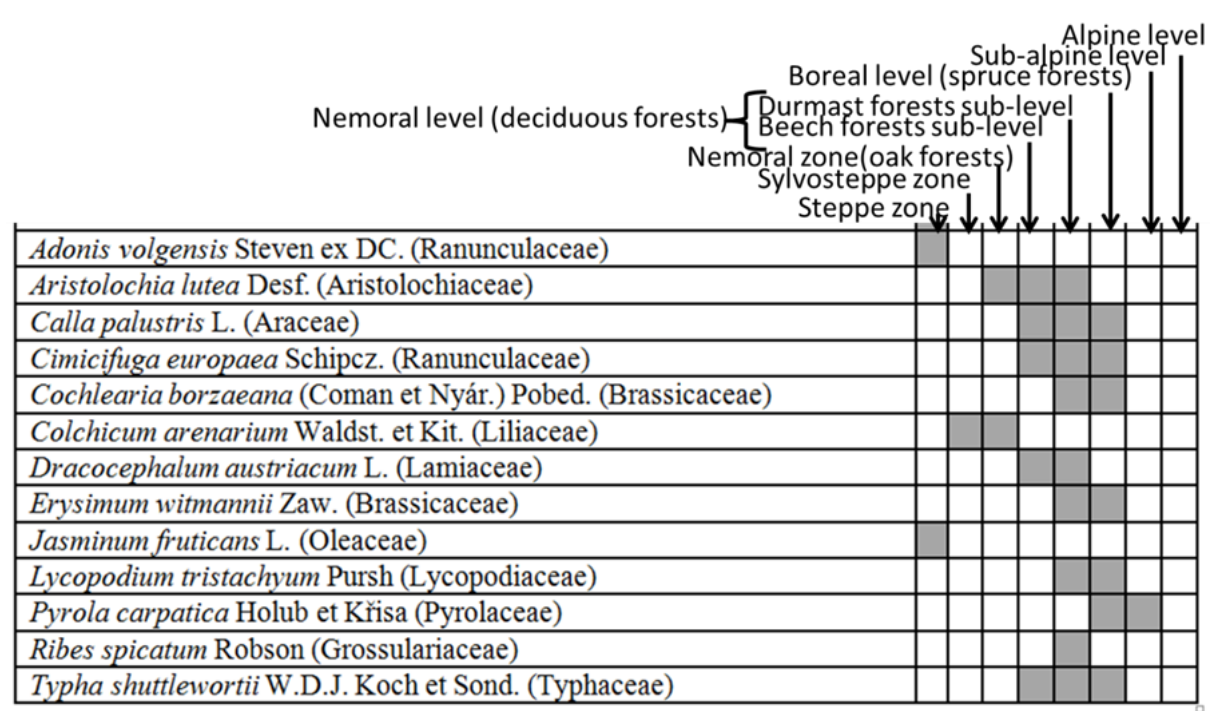

Figure 2.

The distribution of spontaneous medicinal plants strictly forbidden for collection according with Romanian vegetation zones and levels 
In terms of phenology (specifically flowering time), these species flowers in [8]: February - March: Bulbocodium versicolor (Ker Gawl.) Spreng; April - May: Adonis volgensis Steven ex DC., Aristolochia lutea Desf., Ribes spicatum Robson; May - June: Jasminum fruticans L.; May - August: Calla palustris L.; June July: Cochlearia borzaeana (Coman et Nyár.) Pobed., Dracocephalum austriacum L.; June - August: Erysimum witmannii Zaw., Pyrola carpatica Holub et Krrisa, Typha shuttlewortii W.D.J. Koch et Sond.; July August: Cimicifuga europaea Schipcz., Lycopodium tristachyum Pursh; September - October: Colchicum arenarium Waldst. et Kit.

There are synonyms for some species that should be borne in mind by specialists working with these plant species. We used Ciocârlan (2009) [8] to highlight the synonyms: Cochlearia borzaeana (Coman et Nyár.) Pobed. is synonymous with $C$. pyrenaica DC. var. borzaea Coman et Nyár; Lycopodium tristachyum Pursh is synonymous with Diphasiastrum tristachyum (Pursh) Holub and Diphasium tristachyum (Pursh) Rothm.); Ribes spicatum Robson is synonymous with $R$. schlechtendalii Langer, R. rubrum sensu Jancz. et auct. non-L. and $R$. heteromorphum T,opa.

The nomenclature used in Romania [12] sometimes differs from that used internationally [21, 35]: Bulbocodium versicolor (Ker Gawl.) Spreng. is a synonym of Colchicum bulbocodium subsp. versicolor (Ker Gawl.) K. Perss.; Cimicifuga europaea Schipcz. is a synonym of Actaea europaea (Schipcz.) J. Compton; Cochlearia borzaeana (Coman \& Nyaudy) Pobed. is a synonym of Cochlearia pyrenaica $\mathrm{DC}$.

\section{Conclusions}

This paper presents a review, based on literature published since 2007, of the current status of biotechnological approaches of some spontaneous medicinal plants in Romania, with an emphasis on plant species whose collection is forbidden.

Taking into account that the demand for medicinal plants (cultivated and spontaneous) is increasing, there is a priority for the identification and integration of conservation measures (utilising all the tools available including the in vitro methods).

There is a need to expand studies on medicinal plants (whether protected or not) to enable future strategies for increasing knowledge and discovering new valuable compounds.

\section{Acknowledgement}

This work was financially supported by Project No. RO1567-IBB08/2017 from the Institute of Biology Bucharest of Romanian Academy.

\section{Conflict of interest}

The authors declare no conflict of interest.

\section{References}

1. Allan D, Bilz M, Leaman DJ, Miller RM, Timoshyna A, Window J, european red list of medicinal plants. Publications Office of the European Union, Luxembourg, 2014; 1-63.

2. Alves RR, Rosa IM, Biodiversity, traditional medicine and public health: where do they meet? $J$ Ethnobiol Ethnomed., 2007; 3: 1-9.

3. Axini M, Rare and endemic species in ConacuNegresti Valley, Dobrogea, Romania, Global Advances in Biogeography, InTech, London, 2012; 1-374.

4. Bilz M, Colchicum arenarium. The IUCN Red List of Threatened Species 2011: e.T162031A5536314.

5. Bown D, Encyclopaedia of Herbs and their Uses. Dorling Kindersley, London. 1995; 1- 424.

6. Butnariu M, Biodiversity of the phytoconstituents in some plant species potentially toxic. J Biodivers Endanger Species, 2017; 5: 1-9.

7. Chen SL, Yu H, Luo HM, Wu Q, Li CF, Steinmetz A, Conservation and sustainable use of medicinal plants: problems, progress, and prospects. Chinese Medicine, 2016; 11: 1-10.

8. Ciocârlan V, Romanian illustrated flora. Pteridophyta et Spermatophyta, $2^{\text {nd }}$ ed. Revised and completed, Ed. Ceres, Bucharest, 2009, (available in Romanian).

9. Cragg GM, Newman DJ, Biodiversity: A continuing source of novel drug leads. Pure Appl Chem., 2005; 77: 7-24.

10. Dărăban IN, Arsene GG, Turcuș V, Ardelean A, Assessment on bio-economical potential for medicinal plants in salty meadows from the Aradului plain (w. Romania). Studia Universitatis "Vasile Goldiş", Seria Ştiinţele Vieții, 2013; 23(1): 71-78.

11. Department of Ecology (DOE), State of Washington. n.d. Native freshwater plants: Cattail; A common and useful native plant Department of Ecology, State of Washington. Retrieved December 14, 2008.

12. Dihoru G, Boruz V, The list of main spontaneous medicinal plants from Romania. Annals of the University of Craiova - Agriculture, Montanology, Cadastre Series, 2014; XLIV: 328-344.

13. Dihoru G, Negrean G, Romanian red book of vascular plants. Edit. Academiei Române, Bucharest, 2009; 1-630, (available in Romanian).

14. Donno D, Mellano MG, Cerutti AK, Beccaro GL, Biomolecules and natural medicine preparations: analysis of new sources of bioactive compounds from Ribes and Rubus spp. Buds. Pharmaceuticals, 2016; 5: 9(1): 1-13.

15. Dring JV, Kite GC, Nash RJ, Reynolds T, Chemicals in aroids: a survey, including new results for polyhydroxy alkaloids and alkylresorcinols. Botanical Journal of the Linnaean Society, 1995; 117: 1-12.

16. Dubey P, Tiwari A, Gupta SK, Watal G, Phytochemical and biochemical studies of Jasminum officinale leaves. Int J Pharm Sci Res., 2016; 7(6): 2632-2640.

17. Duke JA, Wain KK, Medicinal plants of the world. Computer index with more than 85,000 entries. Plants genetics and germplasm Institute. Agriculture Research Service, Beltsville, Maryland. 1981; 3 vols.

18. El-Hadi MA, Bakri YMN, Yousif GM, Hassan SK, Antiplasmodial activity of some medicinal plants 
used in Sudanese folk-medicine. Environ. Health Insights, 2010; 4: 1-6.

19. European Medicines Agency, 2014, Committee on Herbal Medicinal Products (HMPC) Assessment report on Sisymbrium officinale (L.) Scop., herba.

20. Gorman CE, Potts BM, Schweitzer JA, Bailey JK, Shifts in species interactions due to the evolution of functional differences between endemics and nonendemics: an endemic syndrome hypothesis. PLoS ONE, 2014; 9(10): 1-6.

21. Hassler M, World Plants: synonymic checklists of the vascular plants of the world (version Aug 2017). In: Roskov Y, Abucay L, Orrell T, Nicolson D, Bailly N, Kirk PM, Bourgoin T, DeWalt RE, Decock W, De Wever A, Nieukerken E van, Zarucchi J, Penev L, eds. Species 2000 \& ITIS Catalogue of Life, Netherlands, 2017.

22. Kakasy AZ, New phytochemical data on Dracocephalum species. Ph.D. Thesis, 2006

23. Li JX, Yu ZY, Cimicifugae rhizoma: from origins, bioactive constituents to clinical outcomes. Curr Med Chem., 2006; 13(24): 2927-2951.

24. Liu MG, Xiao GG, Rong P, Zhang Z, Dong J, Zhao H, Li H, Li Y, Pan J, Liu H, Wang W, Zha Q, Ju D, Therapeutic effects of radix dipsaci, Pyrola herb and Cynomorium songaricum on bone metabolism of ovariectomized rats. BMC Complement Altern. Med., 2012, 12: 67-85.

25. McVittie A, Hussain SS, The economics of ecosystems and biodiversity - valuation database manual, 2013; $1-26$.

26. Neuwinger HD, African ethnobotany; poisons and drugs. Chemistry, pharmacology, toxicology. London, Chapman \& Hall. 1994.

27. RBG Kew, The State of the World's Plants Report 2016. Royal Botanic Gardens, Kew.

28. Rashid MA, Akhtar MN, Ashraf A, Nazir S, Ijaz A, Omar NA, Noor S, Basit A, Tareen RB, Chemical composition and antioxidant, antimicrobial and haemolytic activities of Crambe cordifolia roots. Farmacia, 2018; 66(1): 165-171.

29. Sarasan V, Kite GC, Sileshi GW, Stevenson PC, Applications of phytochemical and in vitro techniques for reducing over-harvesting of medicinal and pesticidal plants and generating income for the rural poor. Plant Cell Rep., 2011, 30: 1163-1172.

30. Savarin KIM, Danyel BM, Medicinal plants - Active substances - Properties - Use - A to Z dictionary Enciclopedia. Publisher B.M. Danyel, 2015; (available in Romanian).

31. Săvulescu T, Flora R.P.R., Vol. I-XIII, Edit. Academia Română, 1956, Bucharest, (available in Romanian).

32. Stace $C$, New Flora of the British Isles. (3rd edition) Cambridge: Cambridge University Press, 2010.

33. Tasheva K, Kosturkova G, The role of biotechnology for conservation and biologically active substances production of Rhodiola rosea - endangered medicinal species. Sci World J., 2012; 2012: 1-13.

34. Tămaş M, Muntean S, Muntean L, Duda M, Vârban D, Florian S, Treatise of cultivated and spontaneous medicinal plants - second edition, Muntean LS (coordinator), Ed. Risoprint Cluj-Napoca, 2016, 1- 1065.

35. The Plant List, Vers. 1.1, 2013; www.theplantlist.org.

36. Thierry DH, Achille EA, Sinsin B, Biotechnology in biodiversity conservation: overview of its application for conservation of endangered African tree species. Biotechnology \& Biodiversity, Springer, 2014, 171-181.

37. Uprety Y, Asselin H, Dhakal A, Julien N, Traditional use of medicinal plants in the boreal forest of Canada: review and perspectives. J Ethnobiol Ethnomed., 2012; 8: 1-14.

38. Wang D, He F, Lv Z, Li D, Phytochemical composition, antioxidant activity and HPLC fingerprinting profiles of three Pyrola species from different regions. PLoS ONE, 2014; 9(5): 1-11.

39. www.euromonitor.com

40. www.pfaf.org. 